\title{
István Tózsa
}

\section{Innovation and Identity}

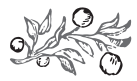

\section{Summary}

Since the spread of mobile Internet, knowledge is being restructured in our minds, because we have access to the entire knowledge of the world. During the last decade, the values that define learned people seem to be changing rapidly. Classical knowledge regarding national historical, geographical and cultural values seems to vanish from the mind of the young generation (the $\mathrm{Z}$ one, born after 1996) and new values belonging to the online environment are gradually replacing them. The results of this change can easily be experienced in higher education, where students seem to have forgotten nearly everything they have learnt in primary and secondary school about their national heritage. This article tries to shed light on the consequences of this ongoing process, and explains the importance of national identity in shaping creativity and innovation. Also, it tries to explain the need to reshape the methodology used in primary and secondary education and to reconsider the national values in our decades of dramatically rapid change in the structure of knowledge.

Keywords: creativity, national identity, innovation, the role of unconscious mind in recording memory units, conflict between classical (old) and new values in education

\section{INTRODUCTION}

The objective of this paper is to draw the attention to a newly discovered close correlation between innovation capacity and the power of national cognitive identity in the human brain, on the one hand. On the other hand, the presentation aims at illustrating the weakness, or even the absence, of national identity in the so-called generation Z (born after 1996) among Hungarian university students at the Corvinus University of Budapest (CUB) and at the National University of Public Service (NUPS). 
According to the latest findings in brain research, the number of memory units in the brain define the capacity of innovation. The more such units the brain has, the more innovative a mind is. Memory units are created in the brain by bioelectric impacts. They exist in the form of links between nervous cells. The strength of bioelectric impact defines the duration of the neural connection. The greater the impact, the longer the neural connection. Dr Tamás Freund, an internationally well-known and reputed professor of the Semmelweis Medical University of Budapest conducted investigations and neurobiological research to find and localise the so-called pacemaker cells in the subconscious mind responsible for regulating the selective memory of the brain. Having been able to localise them, the team sought to identify the external impacts that stimulate these cells. They found that besides emotions, it is the national identity that can stimulate the subconscious pacemaker cells to induce bioelectric impacts creating long-lasting memory units, and thus indirectly innovation capacity, in the conscious crust of the human brain.

In Hungarian higher education there is an optional course on Hungarian national heritage, aimed at improving competence in the preservation, maintenance and management of national values in a business environment. It includes writing tests to prove their familiarity with Hungarian national values to display their level of cognitive national identity, which is significant in innovation capacity and in building a creative personality. An evaluation of the tests proves that between 2013 and 2019, approximately 500 students had extremely low cognitive national identity at CUB and NUPS.

A low level or the complete absence of Hungarian national identity was detected among university students of generation Z. It can be understood as a warning to the government, which communicates the political importance of a nation state and the preservation of Hungarian national values and culture. The risk involved is not only the absence of familiarity with Hungarian history, culture, literature and geography, and thus the absence of a social platform for the Hungarian nation state, but also the impact on the innovation capacity of the young generation. It results in poor urban marketing capacity, as the significant buyers (investors) will not buy a city unless the local population have done so.

\section{THE POWER OF THE MOTHERLAND}

In Greek mythology when Zeus became the king of the Olympian gods, the primordial Giants that came from his grandmother, Gaia, the mother Earth, attacked Zeus and the gods of Mount Olympus to regain their ancient power over the cosmos that had become completely dominated and restructured by the gods. In the battle the Giants proved to be invincible, since as soon as they were stabbed by the gods or struck by Zeus's lightning and fell to the ground, they immediately regained their power from their mother Earth. Finally, the gods had to seek help from Heracles, a mortal man, because he was the only hero who could kill the Giants by lifting them to prevent their contact with Mother Earth and killing them in the air. (In a symbolic language, 
this is a message that only humankind is able to destroy the Earth.) However, this ancient story also manifests the power of the motherland and draws the attention to the importance of place marketing in regional development, and of local and national values in inducing creativity for economic development.

\section{THE ROLE OF IDENTITY IN CREATIVITY}

Professor Tamás Freund is one of the world's most reputed brain researchers, who was awarded the Brain Prize in 2011 with two of his Hungarian colleagues (Professor György Buzsáki and Professor Péter Somogyi) working abroad. The Brain Prize is regarded as the Nobel Prize in brain research. Freund and his team have concentrated on the role of inhibitory 'interneurons', or small nerve cells that release the neurotransmitter $\gamma$-amino butyric acid (GABA), which reduces activity in the nerve cells to which they connect. In the unconscious hippocampus Freund and his team identified three novel types of such cells that connect to other inhibitory nerve cells. He discovered that control over the inhibitory interneurons by other inhibitory cells regulates rhythmic patterns of activity, which are essential for normal memory formation. ${ }^{1}$

What does this mean in simple, everyday language? It is known that unconscious thinking makes up 70\% of the brain activity and its operation has been for the most part hidden from scientific investigation so far (25\% of the brain activity comprises physiologic functions, and only $5 \%$ represents conscious thinking). It is also known that millions of pieces of information reach the conscious brain every day through seeing, hearing, smelling and touching, in public places, at home in the family, at work, via the internet etc. However, the brain creates long-lasting memory cells (from strong bioelectronics discharge between the neurons' axons). Of course, people forget the overwhelming majority of the information obtained through perceptions, no matter how hard they try to remember, especially when they are memorizing for an examination.

The special nervous cells, called "pacemaker" neurons and discovered by Freund, in the subconscious part of the brain prevent the conscious part of the brain from memorizing the information included in these millions of perceptions during the day. So, the number of long-lasting memory cells in the conscious part of the brain remains low because of the pacemaker neurons that control and supervise the information contents of perception. The building blocks of creativity are the long-lasting memory units, and their number is reduced by the subconscious pacemaker cells. A person with 5000 memory units is necessarily less creative than a person with 50,000 or half a million units. The researchers were looking for the impacts that influence the pacemakers to allow strong bioelectronics discharges happen in the conscious brain after perceptions.

They identified the following impacts: (1) emotions, in the first place. If perception is accompanied with emotions, the pacemaker cells in the unconscious allow strong discharges happen among the axons of neurons and thus long-lasting memory units are created that can act as the building blocks of creativity. (2) The second 
impact influencing pacemaker activity was recognised as activity during perception (especially activity in physical - and not digital - communities like parties, co-working, playing, dancing, holiday-making etc.). (3) And finally, the third agent was identified as a place identity with one's motherland. It can be represented in identity with the family and with the birthplace, which may be a city, a region, or a country or nation. In other words, information in the perception of one's birthplace will also make the pacemaker neurons allow the formation of long-lasting memory units in the brain. When people identify themselves with their birthplace, resulting in local patriotism, regional or national patriotism, the local, regional or national identity will make them more creative through building long-lasting memory units.

If a creative personality is to be raised, education policy ought to pay attention to always include emotions (1), activity (2) and maternal, local, regional or national identity in learning (3).

\section{KNOW, LOVE, DEFEND}

Maternal (family), local (urban), regional and national identity can act or can be manifest on three levels: (1) at the cognitive level, showing how much one knows about one's family, city, region and country or nation; (2) at the level of affection, showing one's emotions, love and attitude towards one's family, city, region and country or nation, and (3) at the level of actions, showing what one is ready do in defending, defending, improving, supporting one's family, city, region and country or nation.

The three levels of identity expression accurately correspond to the three steps taken by a local population in place marketing to "buy" their city, region or country. As well-known in place (urban or country) marketing, there are several target groups to buy a place. The first group includes the local population. The most important group includes the managers employed by the investor who can bring foreign direct investment to the city, region or country, and can thus create new jobs and contribute to the local, regional or national budget via taxation. There are many other possible target groups of buyers for a place, like commuting employees, students, patients etc., but their role depends on the presence of big industrial or service companies, universities and hospitals or on the medical treatment infrastructure. However, the buyers who are indispensable for place include tourists, who can also be considered as free means of advertisement, once they had a good time in the city, region or country. In contrast, if tourists are dissatisfied and have unpleasant memories, they can serious destroy the reputation of the city or country.

So in place marketing, the most important regional development tool in attracting capital and investments into a city, region or country, the first buyer, i.e. the local population needs to know their living place before buying it. Once the local population has become familiar with their living place (its geography, history, culture, literature, monuments, pieces of arts etc.), there is a chance that they will also love it. In other words, cognitive identity can easily be followed by affective identity. If the local population loves their place, they are highly likely to proceed to an action-level iden- 
tity in defending it as well. This action can be manifested in willingness to vote, in going on protests, or even in defending the place (usually their country) by force of arms. So when the local or central government sells the place to the local population, the purchasing process is accomplished via (1) getting to know, (2) getting to love and (3) getting to defend the place. We may refer to the place purchase process as the three "gets". ${ }^{2}$

\section{Cognitive identity - THE BASIS OF PLACE MARKETING}

What are included in cognitive identity that serve as ammunition in selling a place to the local population? Cognitive identity includes the circles of local, regional or national values. What are they? The geography, the art collections, such as famous or valuable paintings, statues, monuments and buildings, and the cultural heritage, including events, holidays and festive occasions, exhibitions, theatres, music, gastronomy, traditions, literature, famous and well-known people, the history of the place, the famous and valuable products and the beauties of the landscape. Familiarity with these things is required in the course of place marketing. The first step in selling a city or country is collecting the local or national values in a registry that serves as a value audit of the place. Familiarity with the values makes the cognitive place identity of the local population. Since investors, the main buyers of the place, wish to buy a healthy product, the place needs to be bought by the local population first. The place can be sold to the local population when it is known, loved and defended by the local population. The result of the purchase is a clean settlement, a clean region or a clean country. In this respect the term 'clean' means a healthy product (city or country), with low environment - i.e. physical - pollution, and low crime rate - i.e. social pollution. The investor will buy the place only if it is safe to invest (the social pollution is low), and unpolluted (the environmental pollution is low), because only a clean and healthy place (product) displays and proves that the local population has purchased the place (their product). No one would want to buy a product (a city) the seller itself (the city's population) does not want to buy or has not bought. In this sense, cognitive local regional or national identity is the key factor both in selling a city, region or country, and in local, regional or national economic development. The stronger the local or national identity of the local population is, the better chances the city or the country has to develop its economy and in attracting FDI via place marketing. Cognitive identity also supports creativity, and as in economic development and investments creativity leads to innovations, place identity and innovation go hand in hand. ${ }^{3}$

\section{SyMPTOMS OF DEGLINE IN GOGNITIVE NATIONAL IDENTITY}

At the Corvinus University of Budapest an optional course on Hungarian national heritage was announced in 2013. More than 500 students have completed this course since then. In each grade, there is a short test including questions on Hungarian history, valuable pieces of art, literature and geography. Despite the fact that these 
questions relate to the compulsory national curriculum taught in both primary and secondary schools, no more than $15 \%$ of the students can answer them on average. Perhaps, this suggests that a thorough social investigation of the students' national identity would have a rather disappointing result. The reason why university students forget much of the curriculum content after graduating from secondary school can perhaps be explained by simply memorizing for the final exam, i.e. they try to force their conscious mind to remember the teaching material. When learning is not accompanied by emotions and collective activity - or messages related to local, regional or national identity - knowledge fades away within a couple of months or years without a trace.

The adverse impacts of the absence of a cognitive national identity on the young generation are explained by at least two factors: (1) through the non-creation of longlasting memory units, it influences the conscious capacity of their brains to create ideas and store information, and thus they become less creative than otherwise they might have been; and (2) it reduces local, regional and national (cultural, historical, geographical, geological, artistic etc.) values that can be used in urban, regional or national marketing to attract FDI and thus increase local, regional or national economic development. In short, the absence of sufficient cognitive identity slows economic development. Therefore, the symptoms of decline in national (regional and local) identity among university students require a revision of the teaching methods in primary and secondary schools. What is to be done?

\section{Emotional Intelligence Quotient (EIQ)}

Emotional intelligence is the capability of the mind to recognise and manage emotions in order to guide thinking and behaviour. Nowadays it is getting increasingly known and appreciated in career building as high as, or perhaps even higher than, the traditional IQ. Emotions and the conscious application of emotions should play an ever-increasing role in learning and acquiring knowledge in order to ensure the formation of long-lasting memory units in the conscious mind. Since the members of the new generations are "digital natives", their most common tool, the mobile internet should be admitted and allowed to enter the classroom. Learning should be performed in a community with a wide range of mobile applications. Both emotions and activity should be present in the learning process. Even classrooms can be placed, at least in part, into a virtual space. In addition to classrooms or virtual classrooms, classes may be held at practically any geographical location in the world with accessible virtual space: at volcanoes, waterfalls, in Manhattan or on the Moon. Considering the rapidly developing technology, the implementation of an accessible virtual world is but a matter of years.

During history classes - in order to deepen national identity - using their mobile internet handsets, children can be included in the creation of animated films, perhaps based on romantic and moving love stories, in a real national historical setting. During geography classes, they can either physically travel to places and sights in their 
country, or visit them virtually, in a real-time interactivity with their fellow students and their teacher. During economic courses, children and students may visit factories, company headquarters or banks either in person or in the virtual space, also by realtime interoperability. This will be the reform in education in the near future.

This reform is badly needed as the basic knowledge required for a career had changed very little for many generations before the 21 st century. About 200 books in a home library proved to be enough to make a well-educated, literate person. However, the spread of mobile internet has changed everything forever. The currently available knowledge of the whole world is at everybody's immediate disposal in the hand or in the pocket. Knowledge has continuously been restructuring itself. Therefore, the main device to guide the new generation through the endless ocean of information no longer includes the decisions of the conscious mind, rather the EIQ, rooted in the subconscious mind. The better someone can manage his personal EIQ, the more successful he will be in life and career. Clearly, emotions and activity can also find their places in learning in the digital world. But what about place (local, regional, national) identity? Is it going to lose its importance in acquiring information in the form of long-lasting memory units in the near future? ${ }^{4}$

\section{NEW NATIONAL IDENTITIES}

With the continuous modernisation of the human environment - ever since the Stone Age - tools, traditions and heritage have constantly been transforming. Many of them have been forgotten and new values have emerged. At the beginning of the 21 st century time and technological development have been accelerating at a rate that we are shocked at the pace of forgetting old values, and we are unable to perceive new values replacing them. This also applies to national values and heritage. But the old unconscious demand for identity to the motherland, the birthplace remains, as it is a biologically predestined system. The young generations in the age of acceleration will certainly find their own local, regional and national values. They may not be identical with the classical national values that have been present over numerous generations up to now, but they still will be national. In the case of Hungary, they will be Hungarian values: celebrities, singers, inventions, world records, pieces of new music, new arts, poems, virtual dramas etc.

The Pallas Athene Innovation and Geopolitical Foundation issued an album in Hungarian, in English and in Chinese with the title Hungarians in the Top Ten of the World. This album introduces the success Hungarians have achieved at various world rankings between 2012 and 2015. There are 330 world records held by Hungarians in these few years only in the field of gastronomy, wellness, tourism, festivals and events, professional competitions, music, science and research, creative industries, innovations and sports. They new generations will remember them all because they are involved in it, and these outputs, records are Hungarian values strengthening the Hungarian identity among the youth. The older generations should accept that some of their national values and part of their national heritage are unavoidably doomed to 
vanish due to the very rapid changes in knowledge. At the same time, however, new items of national heritage are continuously being created and the members of the new generations will be as proud of them as their ancestors had been of the classical national heritage. So the supply of national heritage is ensured, the old one will be replaced by the new one in an especially heavily accelerated process currently taking place.

\section{Notes}

1 Chamberland S. and Topolnik L. explain control of the unconscious mind over the activity of the conscious crust and the essence of the discovery of the Hungarian brain researchers in a scientific way (Chamberland and Topolnik, 2012).

2 Maurel MC. explains the significance of local or territorial identity in regional and local development i.e. innovations in the economy, using Central European and Hungarian examples (Maurel, 2016).

3 Kavaratzis, M. and Ashworth, G. J. present the role of identity in urban marketing in a scientific approach (Kavaratzis and Ashworth, 2005).

4 Akduman, G. et al. introduce EI as it can be experienced in different generations (Akduman, 2015).

\section{REFERENCES}

Akduman, G.; Yüksekbilgili, Z. and Hatipoğlu Z. (2015): A Research about Emotional Intelligence on Generations. International Journal of Advanced Multidisciplinary Research and Review, Vol. 3, No. 4, www.researchgate.net/publication/270904904.

Chamberland, S. and Topolnik, L. (2012): Inhibitory Control of Hippocampal Inhibitory Neurons. Frontiers in Neuroscience, Vol. 6, https://doi.org/10.3389/fnins.2012.00165.

Kavaratzis, M. and Ashworth, G. J. (2005): City Branding: An Effective Assertion of Identity or a Transitory Marketing Trick? Nederlands Aardrijkskundig Genootschap, Vol. 96, No. 5, https://doi.org/10.1111/j.14679663.2005.00482.x.

Maurel, M. (2016): Building Local Development of Territorial Identity. Joseph Károlyi Foundation, L'Harmattan, https://hal.archives-ouvertes.fr/hal-01409764/document. 